\title{
Assessment of Functional Properties Flours from Seven Local Varieties of Cassava (Manihot esculenta Crantz) Consumed in Côte d'Ivoire
}

\author{
Marise Amaco Kacou', Gbocho Serge Elvis Ekissi ${ }^{1 *}$, Bomo Catherine Ebbah-Djedji², \\ Boni N'zué ${ }^{3}$ and Patrice Lucien Kouamé ${ }^{1}$
}
${ }^{1}$ Laboratory of Biochemistry and Food Technology, University Nangui Abrogoua (Abidjan, Côte d'Ivoire), 02 BP 801 Abidjan 02, Côte d'Ivoire
${ }^{2}$ CNRA (National Center for Agronomic Research), Research Station on Technology (Abidjan, Côte d'Ivoire)
${ }^{3}$ CNRA (National Center for Agronomic Research), Research Station on Food Crops (Bouaké, Côte d'Ivoire)

*Corresponding author

\section{A B S T R A C T}

The present research was carried out to study some functional properties of seven local flours (Agbablé3, Bonoua2, Bondoukou4, Boufouh3, Boufouh4, Soclopouopo3, Totoba2)

Keywords

Côte d'Ivoire,

Flours, Functional properties, Manihot esculenta, Varieties cassava (Manihot esculenta Crantz) varieties. The functional properties (hydrated density, apparent density, porosity, water absorption capacity, oil absorption capacity, hydrophillipophil ratio, water solubility index, emulsion capacity, foam capacity, wettability, gelatinization temperature, blue value index) of were evaluated. The Boufouh3 variety flour had highest hydrated density $(0.83 \pm 0.02 \mathrm{~g} / \mathrm{ml})$, emulsion capacity $(1.86 \pm 0.81 \%)$, wettability $(32.66 \pm 2.87 \mathrm{~s})$. Boufouh4 variety flour had the highest values in apparent density $(0.62 \pm 0.01)$, foam capacity $(21.42 \pm 1.5 \%)$ and blue value index $(63.3 \pm 0.01 \%$ $\mathrm{DO} / \mathrm{mg})$. Agbablé3 variety flour had highest water absorption capacity $(97.28 \pm 6.23 \%)$. Soclopouopo3 variety flour had the highest values in porosity $(51.25 \pm 1.86 \%)$ and Hydrophil-lipophlil ratio $(0.97 \pm 0.02)$. Totoba2 had highest water solubility index $(27.56 \pm 0.35 \%)$. Bondoukou4 variety flour had the highest values in gelatinization temperature $\left(72 \pm 0.82^{\circ} \mathrm{C}\right)$ and oil absorption capacity $(108.15 \pm 2.25 \%)$. The functional properties of flours studied show many differences and few similarities. Flours varieties Boufouh3 and Boufouh4 have higher values in functional properties compared to others.

\section{Introduction}

Cassava (Manihot esculenta Crantz), native to Latin America (Hillocks et al., 2002a), is growing in nearly 100 countries (all developing), including more than 30 African countries (Djilemo, 2007). Cassava (Manihot esculenta Crantz) is a widely grown tuber and staple food for millions of people in the tropics of Africa, Latin America and Asia. At the global level, in terms of annual production, it is the fifth most important food crop after maize, rice, wheat and potatoes (FAOSTAT, 2011). Cassava is a major root crop and an 
important staple food for more than 500 million people in developing countries (Djoulde, 2005; Falade, 2010). Cassava cultivation is traditionally produced in small family farms and mainly processed and consumed at the household level. Cassava is a cheap, easily available and reliable source of carbohydrates, especially in the case of food shortages. This drought-resistant crop has always played an important role in preventing famine in West, East and Southern Africa (Nweke, 2005).

World production is estimated at 278.7 million tonnes, of which Nigeria is the world's largest producer with 54.832 million tonnes, or $20.3 \%$ of world production (FAOSTAT, 2014).

Cassava (Manihot esculenta Crantz) is one of the most important sources of commercial starch production in tropical and subtropical countries (Moorthy, 2004).

Cassava has played and continues to play a major role in efforts to alleviate food crises because of its efficient food production, available all year round, which is extremely tolerant of stressful conditions and to peasant agriculture and agriculture food system in Africa (Maziya -Dixon et al., 2007).

Cassava is highly perishable and the presence of cyanogenic compounds in its roots requires treatment just after harvest (Westby, 2002). One of the best ways to preserve them is to turn them into flour and / or starch (Perez et al., 2005). Thus, cassava flour is an ingredient increasingly used in the manufacture of a large number of commercial food products. Indeed, it is used in bakery and baking where it goes into the preparation of cookies, cakes, ice cream and ice cream cones, flakes, pasta, puff pastry, etc. (Akoroda, 2007).

In some countries, such as Benin and Nigeria, people have quickly recognized the need to process cassava into byproducts (Cossettes, Chikwangue, Fufu, Gari, Attieke, Tapioca (Bokanga, 2001) whose gain is generally higher than fresh roots

In Côte d'Ivoire, several meals (placali, kongondé, bédèkouma, gari, etc.) were obtained from cassava roots (Kakou, 2000, Amani et al., 2007). Despite its great importance, cassava is subject to several problems such as diseases, low productivity and low nutritional value. Many studies have been undertaken to solve these problems.

Thus, new varieties of cassava were obtained in Côte d'Ivoire by the CNRA (National Center for Agronomic Research) after several crosses between two original varieties V4 (IAC, white color) and V23 (Anango agba, yellow color). They had higher root yields and were more resistant to diseases and pests than existing local varieties (N'zué et al., 2001). However, for these new varieties, food composition data that are very important in the area of nutrition and health (Sodjinou, 2006) were unknown. The properties (biochemical, physico-chemical, functional) on these new varieties remain unknown although consumed by populations.

The aim of this study is to determine some functional properties of flours from seven varieties (Bonoua2, Boufouh3, Boufouh4, Bondoukou4, Agbablé3, Soclopouopo3, Totoba2) of cassava in order to be able to popularize and promoted their use in various fields.

\section{Materials and Methods}

\section{Plant material}

The roots of seven new improved cassava (Agbablé3, Bonoua2, Boufouh3, Boufouh4, Bondoukou4, Soclopouopo3, Totoba2) of twelve month sold were harvested from 
CNRA (National Center for Agronomic Research) experimental plot (Bouake, Côte d'Ivoire).Roots were put in coolers to preserve their fresh state, they were transported to the Laboratory of Biochemistry and Food Technology of University of Nangui Abrogoua (Abidjan, Côte d'Ivoire) where study was conducted.

\section{Flour sample preparation}

Fresh roots were peeled manually and cut into small pieces with a inox knife. The pieces obtained were washed and dried in an oven at $45{ }^{\circ} \mathrm{C}$ for 48 hours. Dry pieceswere crushed and sieved to obtain the raw cassava flour that has been used for various analyzes.

\section{Methods}

\section{Functional properties analysis}

Water absorption capacity and solubility index

The water absorption capacity (WAC) and the water solubility index (WSI) of the flours are determined according to the methods of Phillips and al. (1988) and Anderson and al. (1969).

Two (2) g of flours (M0) are dissolved in 50 $\mathrm{ml}$ of distilled water contained in a centrifuge tube. This mixture is stirred for 30 minutes with a stirrer and then kept in a water bath at $37^{\circ} \mathrm{C}$. for 30 minutes. It is then centrifuged at $5000 \mathrm{rpm}$ for 15 minutes. The pellet obtained (M2) is weighed and then dried at $105^{\circ} \mathrm{C}$ to a constant mass (M1). WAC and WSI are calculated from the following relationships:

$$
\begin{aligned}
& \text { WAC }(\%)=\frac{M 2-M 1}{M 1} \times 100 \\
& \text { WSI }(\%)=\frac{M 0-M 1}{M 0} \times 100
\end{aligned}
$$

\section{Oil absorption capacity}

The oil absorption capacity (OAC) of the flours is determined according to the method of Sosulski (1962). One (1) g (M0) of flours is dissolved in $10 \mathrm{ml}$ of oil. The mixture is stirred for 30 minutes at room temperature using a mechanical stirrer and then centrifuged at $4500 \mathrm{rpm}$ for 10 minutes. The pellet recovered is weighed (M1). The oil absorption capacity (OAC) is calculated from the following formula:

$\mathrm{OAC}(\%)=\frac{\mathrm{M} 1-\mathrm{M} 0}{\mathrm{M} 0} \times 100$

\section{Apparent density and porosity}

The apparent density (AD) of the flours is determined according to the method of Narayana Rao and Narasinga (1994). Fifty (50) grams of flour or starch (ME) are placed in a $100 \mathrm{ml}$ graduated cylinder.

The volume $\left(\mathrm{V}_{0}\right)$ of this sample is noted after a good leveling with a spatula (without beating the specimen on the bench). Then, the specimen is gently tapped on the bench until a constant volume noted $\mathrm{Vt}$.

$$
\mathrm{AD}\left(\frac{\mathrm{g}}{\mathrm{ml}}\right)=\frac{\mathrm{ME}}{V t} \mathrm{P}(\%)=\frac{\mathrm{V} 0-\mathrm{Vt}}{\mathrm{V} 0} \mathrm{x} 100
$$

\section{Hydrated density}

A mass of $0.5 \mathrm{~g}$ of flours is carefully added to prevent adhesion to the walls of the test tube with $5 \mathrm{ml}$ of distilled water contained in a graduated $10 \mathrm{ml}$ test tube.

The difference between the volume of the water before (V0) and after $(\mathrm{Vt})$ the addition of the sample is marked as the volume of water displaced in $\mathrm{ml}$. The result is expressed in grams of flour or starch per $\mathrm{ml}$ of displaced water. 
$\mathrm{HD}(\mathrm{g} / \mathrm{ml})=\frac{\mathrm{V} 0-\mathrm{Vt}}{\mathrm{V} 0}$

\section{Hydrophilic-lipophilic ratio}

The hydrophilic-lipophilic ratio $(\mathrm{R})$ as defined by Njintang and al. (2001), is calculated by comparing the water absorption capacity with the oil absorption capacity. It is a report that evaluates the comparative affinity of flours for water and for oil.

$\mathrm{HLR}=\frac{\text { WAC }}{\mathrm{OAC}}$

\section{Emulsion capacity}

The emulsion capacity (EC) of the flours is determined according to the method of Beuchat (1977) slightly modified. Two (2) g of flours (ME) are dispersed in $50 \mathrm{ml}$ of distilled water contained in an Erlenmeyer flask. The mixture is homogenized with a magnetic stirrer for 20 minutes. The suspension is transferred to a centrifuge tube and then ten (10) $\mathrm{ml}$ of oil (V0, density $0.88 \mathrm{~g}$ / $\mathrm{ml})$ are added thereto. This mixture is stirred continuously for 5 minutes and then heated in a water bath for 15 minutes at $85^{\circ} \mathrm{C}$. The tube is removed, then cooled to room temperature $\left(25^{\circ} \mathrm{C}\right)$ for $10 \mathrm{~min}$ and centrifuged at 4500 rpm until the volume of oil (V1) separated from the emulsion (V2) becomes constant. The results are expressed as a percentage of emulsified oil per gram of flour used.

EC $(\%)=\frac{V 2}{M E} \times 100$

\section{Foam capacity (FC) and foam stability (FS)}

The foam capacity (FC) and foam stability (FS) of flours are determined according to the method of Coffman and Garcia (1977). Three (3) grams of flours are transferred into a graduated $50 \mathrm{ml}$ test tube previously dried in an oven at $50{ }^{\circ} \mathrm{C}$. The flour is leveled and the volume noted (V0). Then, thirty (30) $\mathrm{ml}$ of distilled water is added to the sample to facilitate the dispersion of the flour in the test tube and the volume is also noted (volume before homogenization); then the test tube is vigorously stirred by hand and the new volume is read on the test piece (volume after homogenization).

The volume of the foam obtained is calculated by making the difference between the volume after homogenization and the volume before homogenization. The test piece is allowed to rest on the bench until the foam collapses (Mariod et al., 2010) and at each time interval (every $10 \mathrm{~min}$ ), the volume of the foam is determined. The foaming capacity (FC) and the stability of the foam (SF) of the flours are calculated from the following formulas:

FC $(\%)=\frac{\text { Vol after homogenization }- \text { Vol before homogenization }}{\text { Vol before homogenization }}$

FS $(\%)=\frac{\text { Volume of the foam at time } t}{\text { Volume initial of the foam }} \times 100$

\section{Wettability}

The wettability of the flours is determined according to the technique of Onwuka (2005). One (1) gram of flour is placed in a graduated $25 \mathrm{ml}$ test tube having a diameter of $1 \mathrm{~cm}$. A finger is placed on the opening of the specimen (to avoid pouring the sample by reversing it).

The finger closing the specimen is placed at a height of $10 \mathrm{~cm}$ from the surface of a $600 \mathrm{ml}$ beaker containing $500 \mathrm{ml}$ of distilled water. The finger is removed and the sample is poured into the beaker. Wettability is the time needed for the sample to become completely wet. 


\section{Dispersibility}

The dispersibility (D) of the flours is determined according to the method described by (Mora-Escobedo et al., 2009). The dispersibility of the flour is defined as the difference between the total volume (V0) of the particles just after the stirring manually and the volume $(\mathrm{Vt})$ of the deposited particles recorded at time $t$ min.

$D(\%)=\frac{V 0-V t}{V 0} \times 100$

\section{Point of gelatinization}

The method of Narayana Rao and Narasinya (1982) is used to determine the gelling temperature. Ten (10) $\mathrm{g}$ of flour sample is dispersed in a $250 \mathrm{ml}$ beaker containing 100 $\mathrm{ml}$ of distilled water. A thermometer is blocked on a stand with its bulb immersed in the suspension under a magnetic stirrer heater. Heating and stirring continued until frost was obtained and the corresponding temperature was recorded.

\section{Statistical analysis}

All analyses were performed in triplicates. Results were expressed by means of \pm SD. Statistical significance was established using Analysis of Variance (ANOVA) models to estimate the functional properties of cassava flours. Means were separated according to Duncan's multiple range analysis ( $\mathrm{p} \# 0.05$ ), with the help of the software Statistica (StatSoft Inc, Tulsa USA Headquarters) (Duncan, 1955).

\section{Results and Discussion}

The functional properties of flours from seven local cassava varieties are presented in Table 1. The functional properties differ significantly $(\mathrm{p}<0.05)$ one variety to another.
Functional properties or characteristics are the intrinsic physico-chemical properties that reflect the complex interaction between the composition, structure, confirmation and physicochemical properties of protein and other food components and the nature of environment in which these are associated and measured (Kinsella,1976). Functional properties of flours play important role in the manufacturing of products.

Flour density is important for determining packaging and handling requirements according to (Ezeocha et al., 2011).

Hydrated density values of seven cassava varieties ranged between $0.68 \pm 0.02$ and 0.83 $\pm 0.01 \mathrm{~g} / \mathrm{ml}$. Totoba2 variety had the lowest value $(0.68 \pm 0.02 \mathrm{~g} / \mathrm{ml})$ and the varieties Boufouh3 and Agbablé3 the highest values $(0.83 \pm 0.01 \mathrm{~g} / \mathrm{ml})$.These values are higher than the taro meal $(0.42$ and $0.45 \mathrm{~g} / \mathrm{ml})$ obtained by Himeda (2012).

Apparent density values ranged between $0.49 \pm 0.01$ and $0.62 \pm 0.01 \mathrm{~g} / \mathrm{ml}$. Boufouh4 variety had the highest value $(0.62 \pm 0.01 \mathrm{~g} / \mathrm{ml})$ and Bonoua2 variety the lowest value $(0.49 \pm$ $0.00 \mathrm{~g} / \mathrm{ml})$. Apparent density values of seven flours of cassava are lower than yam (Dioscorea bulbifera) apparent density value $(0.72 \pm 0.02 \mathrm{~g} / \mathrm{ml})$ according to Achy et al., (2017), wheat flour $(0.71 \mathrm{~g} / \mathrm{ml})$ found by Akubor (2007). The high apparent density increases the absorption capacity of the powder particles, which enhances their ability to disperse (Udensi and Okaka, 2000; Ekwu et al., 2005).

Porosity values varied from $40.95 \pm 1.35$ to $51.25 \pm 1.86 \%$. Soclopouopo3 variety flour had the highest porosity $(51.25 \pm 1.86 \%)$ while Totoba2 variety the lowest $(40.95 \pm 1.35 \%)$. The varieties Agbablé3, Soclopouopo3 and Totoba2 hadporosities values not differ significantly $(\mathrm{p}<0.05)$. 
According to Onuegbu et al., (2001), high water absorption capacity is needed in baked foods such as bread. The water absorption capacity varies with size, shape, presence of protein, carbohydrate and lipids, $\mathrm{pH}$ and salts (Ezeocha et al., 2011).

Water absorption capacity (WAC) is a critical function of protein in various food products like soups, dough and baked products (Adeyeye and Aye, 1998). Water binding capacity is affected by the presence of minerals such as phosphorus in starch, where high phosphorus starches have high water binding capacities (Zuluaga et al., 2007).

The ability of flour to absorb water is a very important property of all flours in food preparations, in swelling and consistency of products as well as in cooking applications (Niba et al., 2001). The water absorption capacity (WAC) of flours from the seven varieties of cassava varied from $75.57 \pm 6.40$ (Agbablé3) to $97.28 \pm 6.23 \%$ (Totoba2). The WAC of seven flours are lower than Voandzou flour WAC (199.26 to 239.75\%) reported by Diallo et al., (2015), yam (Dioscoreasp) flour WAC $(182.3 \pm 4.1$ to
$390.7 \pm 4.4 \%$ ) (Dumont, 1995). This water absorption capacity plays an important role in the choice of flours for thickening sauces and soups (Kaur et al., 2013).

The solubility index in water seven flours ranged between $10.13 \pm 2.15$ (Boufouh 3) and $27.56 \pm 0.35 \%$ (Totoba 2). Thus, those of the yam Dioscorea dumetorum (12.0 \pm 0.4 to 15.0 $\pm 0.1 \%$ ) (Mbome, 1991) are included among those of the seven varieties.

Oil absorption capacity (OAC) is attributed mainly to the physical entrapment of oils. It is an indication of the rate at which the protein binds to fat in food formulations (Singh et al., 2005).

Dinor oil absorption capacity of flours varied

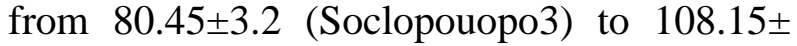
$2.25 \%$ (Bondoukou4). The lower oil absorption capacity of cassava flours could be due to low hydrophobic proteins which show superior binding of lipids (Adeleke and Odedeji, 2010).The variation of the absorption capacity of oils (OAC) in flours is associated with the presence of non-polar chains (Njintang et al., 2003).

Fig.1 Dispersibility of flours from seven varieties of cassava

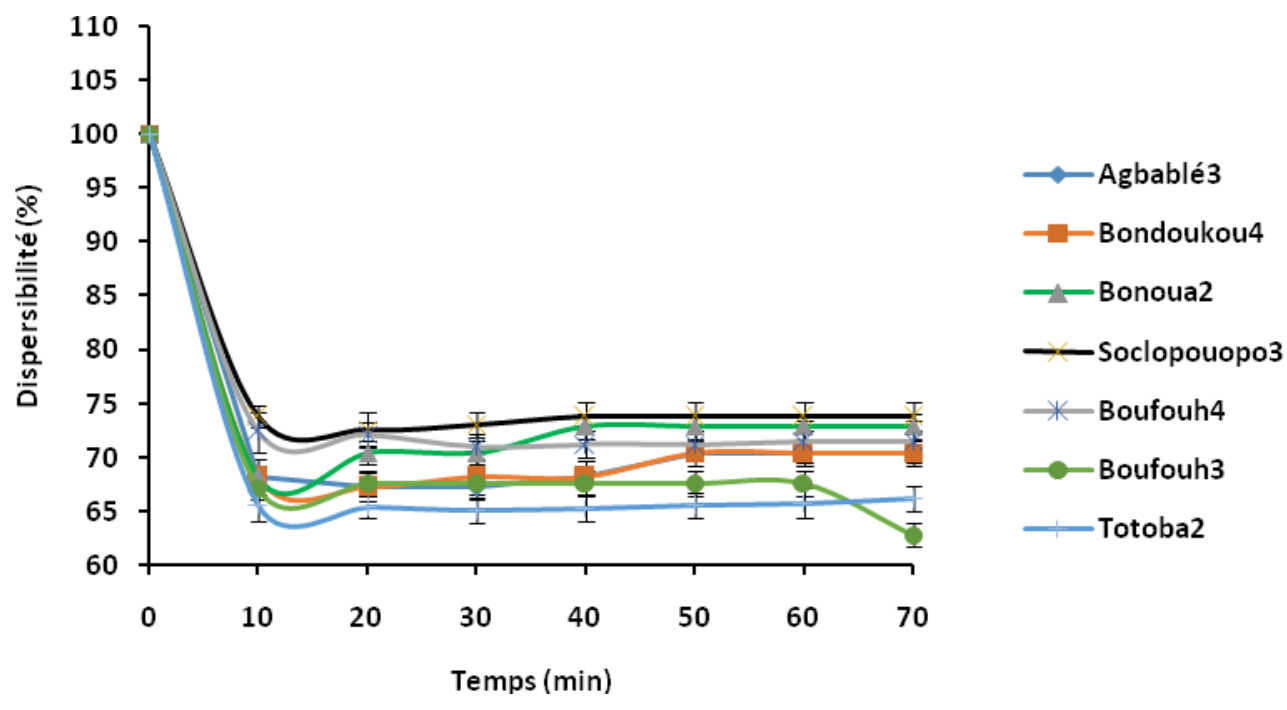


Table.1 Functional properties flours from seven local varieties of cassava (Manihot esculenta Crantz)

\begin{tabular}{|l|l|l|l|l|l|l|l|}
\hline \multirow{2}{*}{ Properties } & \multicolumn{7}{|c|}{ Cassava varieties } \\
\cline { 2 - 8 } & Agbablé3 & $\begin{array}{l}\text { Bondou } \\
\text { kou4 }\end{array}$ & Bonoua2 & $\begin{array}{l}\text { Soclo- } \\
\text { pouopo3 }\end{array}$ & Boufouh4 & Boufouh3 & Totoba2 \\
\hline HD (g/ml) & $0,83 \pm 0,01^{\mathrm{a}}$ & $0,76 \pm 0,02^{\mathrm{bc}}$ & $0,74 \pm 0,01^{\mathrm{c}}$ & $0,81 \pm 0,02^{\mathrm{ab}}$ & $0,82 \pm 0,01^{\mathrm{a}}$ & $0,83 \pm 0,02^{\mathrm{ab}}$ & $0,68 \pm 0,01^{\mathrm{d}}$ \\
\hline AD (g ml) & $0,50 \pm 0,01^{\mathrm{a}}$ & $0,58 \pm 0,01^{\mathrm{c}}$ & $0,49 \pm 0,00^{\mathrm{a}}$ & $0,50 \pm 0,00^{\mathrm{a}}$ & $0,62 \pm 0,01^{\mathrm{d}}$ & $0,57 \pm 0,01^{\mathrm{b}}$ & $0,50 \pm 0,02^{\mathrm{a}}$ \\
\hline P $(\%)$ & $44,60 \pm 0,85^{\mathrm{b}}$ & $42,65 \pm 0,22^{\mathrm{ab}}$ & $51,16 \pm 1,19^{\mathrm{d}}$ & $51,25 \pm 1,86^{\mathrm{d}}$ & $47,85 \pm 0,71^{\mathrm{c}}$ & $47,85 \pm 0,79^{\mathrm{c}}$ & $40,95 \pm 1,35^{\mathrm{a}}$ \\
\hline WAC $(\%)$ & $97,28 \pm 6,23^{\mathrm{d}}$ & $95,64 \pm 4,01^{\mathrm{cd}}$ & $87,38 \pm 3,95^{\mathrm{bc}}$ & $78,53 \pm 5,46^{\mathrm{ab}}$ & $81,98 \pm 2,88^{\mathrm{ab}}$ & $91,93 \pm 4,45^{\mathrm{cd}}$ & $75,57 \pm 6,40^{\mathrm{a}}$ \\
\hline $\begin{array}{l}\text { OAC } \\
\text { (Dinor) \% }\end{array}$ & $106,25 \pm 3,85^{\mathrm{c}}$ & $108,15 \pm 2,25^{\mathrm{b}}$ & $98,9 \pm 2,1^{\mathrm{b}}$ & $80,45 \pm 3,2^{\mathrm{d}}$ & $85,25 \pm 3,75^{\mathrm{a}}$ & $100,7 \pm 3,80^{\mathrm{b}}$ & $88,75 \pm 0,95^{\mathrm{a}}$ \\
\hline HLRD & $0,91 \pm 0,03^{\text {abc }}$ & $0,88 \pm 0,02^{\mathrm{ab}}$ & $0,88 \pm 0,08^{\mathrm{ab}}$ & $0,97 \pm 0,02^{\mathrm{c}}$ & $0,96 \pm 0,03^{\mathrm{bc}}$ & $0,91 \pm 0,04^{\mathrm{abc}}$ & $0,85 \pm 0,05^{\mathrm{a}}$ \\
\hline WSI \% & $18,30 \pm 2,86^{\mathrm{b}}$ & $19,63 \pm 1,23^{\mathrm{b}}$ & $12,36 \pm 2,19^{\mathrm{a}}$ & $13,03 \pm 2,0^{\mathrm{a}}$ & $2,36 \pm 1,01^{\mathrm{c}}$ & $10,13 \pm 2,15^{\mathrm{a}}$ & $27,56 \pm 0,35^{\mathrm{d}}$ \\
\hline EC $(\%)$ & $1,80 \pm 0,16^{\mathrm{c}}$ & $1,97 \pm 0,17^{\mathrm{g}}$ & $1,88 \pm 0,24^{\mathrm{f}}$ & $1,82 \pm 0,00^{\mathrm{d}}$ & $1,56 \pm 0,16^{\mathrm{a}}$ & $1,86 \pm 0,81^{\mathrm{e}}$ & $1,75 \pm 0,04^{\mathrm{b}}$ \\
\hline (FC) $(\%)$ & $13,63 \pm 1,00^{\mathrm{b}}$ & $8,82 \pm 0,5^{\mathrm{a}}$ & $5,71 \pm 0,2^{\mathrm{c}}$ & $13,63 \pm 0,9^{\mathrm{b}}$ & $21,42 \pm 1,5^{\mathrm{e}}$ & $9,09 \pm 0,41^{\mathrm{a}}$ & $7,14 \pm 0,05^{\mathrm{d}}$ \\
\hline W (S) & $27,0 \pm 5,10^{\mathrm{a}}$ & $31,50 \pm 1,08^{\mathrm{a}}$ & $15,18 \pm 1,65^{\mathrm{b}}$ & $15,33 \pm 2,5^{\mathrm{b}}$ & $32,0 \pm 3,56^{\mathrm{a}}$ & $32,66 \pm 2,87^{\mathrm{a}}$ & $28,33 \pm 4,92^{\mathrm{a}}$ \\
\hline PG ( $\left.{ }^{\circ} \mathbf{C}\right)$ & $68 \pm 0,47^{\mathrm{b}}$ & $72 \pm 0,82^{\mathrm{c}}$ & $70 \pm 0,45^{\mathrm{a}}$ & $70 \pm 0,81^{\mathrm{a}}$ & $70 \pm 0,82^{\mathrm{a}}$ & $69 \pm 0,47^{\mathrm{ab}}$ & $70 \pm 0,47^{\mathrm{a}}$ \\
\hline
\end{tabular}

*All results are mean \pm standard error for three replicates

*Different alphabets in superscript in each row show significant difference between values

Hydrophilic-lipophilic ratios of seven flours varied from $0.87 \pm 0.05$ (Totoba 2 ) and $1.04 \pm$ 0.02 (Soclopouopo3). There is no significant difference between all these varieties. These ratios are less than 1 , which clearly shows that cassava flours obtained have a higher affinity for Dinor oil than water.

Emulsion activity and stability (\%) Protein being the surface active agents can form and stabilize the emulsion by creating electrostatic repulsion on oil droplet surface (Kaushal et al., 2012). The emulsion capacity of flours ranged between $1.56 \pm 0.11 \%$ (Boufouh4) and $1.86 \pm 0.17 \%$ (Boufouh3).

The temperature at which gelatinization of starch take place is known as the gelatinization temperature (Sahay and Singh, 1996). The study revealed that the flour which was higher in starch content took lowest temperature for gelatinization. The gelatinization point of seven flours ranged between $68 \pm 0.47{ }^{\circ} \mathrm{C}$ (Agbablé) and $72 \pm 0.82$ ${ }^{\circ} \mathrm{C}$ (Bondoukou4). The Bonoua2, Soclo pouopo3, Boufouh4 and Totoba2 varieties all have the same values $\left(70{ }^{\circ} \mathrm{C}\right)$. The gelatinization point of the flours of 7 varieties of cassava is between 68 and $72^{\circ} \mathrm{C}$. According to Amani (2002), the gelatinization temperature of yams florido $\left(75.8^{\circ} \mathrm{C}\right)$, kponan $\left(73.5^{\circ} \mathrm{C}\right)$ are higher than the seven varieties cassava studied. In addition, the values of cassava Bonouan $\left(70^{\circ} \mathrm{C}\right)$, Ouanga $\left(69^{\circ} \mathrm{C}\right)$ and Akaman $\left(70^{\circ} \mathrm{C}\right)$ flours reported by Zoumenou et al., (1994) are in values obtained in this study.

Foam capacity (FC, \%) and Foam stability (FS, \%) Foam capacity of protein refers to the amount of interfacial area that can be created by the protein (Fennama, 1996). Foam is a colloidal of many gas bubbles trapped in a liquid or solid. Small air bubbles are surrounded by thin liquid films. Foams are used to improve the texture, consistency and appearance of foods (Akubor, 2007). Flours with high foaming ability could form large air bubbles surrounded by thinner a less flexible protein film. This air bubbles might be easier to collapse and consequently lowered the foam stability (Jitngarmkusol et al., 2008). The foaming capacity of flours ranged between $5.71 \pm 0.2$ (Bonoua2) and $21.42 \pm$ $1.5 \%$ (Boufouh4). There is no significant difference $(\mathrm{p}<0.05)$ between varieties 
Bondoukou4, Boufouh3 and Agbablé3, Soclopouopo3.

The wettability of seven flours of cassava varied from $15.18 \pm 1.65 \mathrm{~s}$ (Bonoua2) and $32.66 \pm 2.87 \mathrm{~s}$ (Boufouh3). Wettability is a function of the ease of dispersion with respect to the displacement in the water of the sample. The sample with lowest wettability time would dissolve in the water more rapidly than samples with higher wettability (Ubbor et al., 2006). The Boufouh3, Boufouh4 and Bondoukou4 varieties have the closest and the highest values, but there is no significant difference $(\mathrm{p}<0.05)$ between Totoba 2 and Agbablé3 varieties.

Then the flours of these two varieties dissolve more quickly than the other varieties. According to Schuck (2011), a powder is considered wettable if its wettability time is less than 60s and very wettable if it is less than 30s. In addition, the values obtained Bonoua2, Agbablé3, Totoba2 and Soclopouopo3 are less than 30 s so the seven flours of cassava are very wettable.

The dispersibility percentage is an indicator of good water absorption capacity of flours and an indicator of good quality of the gel according to Eke-Ejiofor et al., (2014). The dispersibility of flour gives an indication of the suspension of the particles in water (Mora-Escobedo et al., 1991). Kulkarni et al., (1991) reported that dispersibility is associated with fine particle size. The dispersibilities of seven flours from cassava varied from 62.85 (totoba2) to $73.80 \%$ (Soclopouopo3). According to Sara et al., (2008) a high value of dispersibility increases the emulsifying and foaming properties of proteins. The values obtained are higher than those of Himeda (2012) on taro flour (29 and $30.56 \%)$. The values reported by Eke-Ejiofor et al., (2011), which are 55-66\% (local rice) and $50-70 \%$ (Caprice rice), are in the range of the seven flours of cassava (Fig. 1).

The apparent and hydrated densities of the flours are all less than 1 with porosities ranged from 40.95 to $51.25 \%$. The seven flours are very wettable with a wettability of less than 30s and absorb more oil than water with hydrophilic-lipophilic ratios less than 1 . The emulsifying capacities and foaming properties of the flours are low and due to the low protein content in the flours. These flours have good dispersibility values giving a reconstitution capacity of a fine and consistent dough. As for the gelatinization points of the seven flours are around $70{ }^{\circ} \mathrm{C}$. The functional properties flours of the seven varieties of cassava (Manihot esculenta Crantz) studied demonstrate their ability to use in various fields.

\section{Acknowledgements}

This work was supported by Ph.D. grant to the first author. The authors thank Biocatalysis and Bioprocessing Laboratory of Nangui Abrogoua University (Abidjan, Côte d'Ivoire) for its technical assistance and CNRA (National Center for Agricultural Research) for biological material (seven varieties of cassava).

\section{References}

Achy, J.Y., Ekissi, E.S.G., Koffi, B.K.P., Koné, T.M.F and Kouamé, L.P. 2017. Effet des temps d'ébullition et de cuisson sur les propriétés fonctionnellesde farine d'igname aérienne (Dioscorea bulbifera) cv Dugu-won bulbilles en Côte d'Ivoire. Int. J. Agron. Agri. R. 10 (2): 1-12.

Adeleke, R.O. and Odedeji, JO. 2010. Functional Properties of Wheat and Sweet Potato Flour Blends, Department of Food Technology, Osun State Polytechnic, Iree, Osun State, Nigeria. 
Adeyeye, E.I., Arogundade, L.A., Akintayo, E.T., Aisida, O.A. and Alao, PA. 2000. Calcium, zinc and phytate interrelationships in some foods of major consumption in Nigeria. Journal of Food Chemistry. 71:435-441.

Akoroda, M.2007. Consumption and organization of the cassava market in West Africa. In "Potentialities for processing cassava (Manihot esculenta Crantz) in West Africa",

Akubor, P.I. 2007. Chemical, functional and cooking properties of biscuits from soybean meal and corn blends. J Food Sci Technol. 44 (6): 619-622.

Amani, G., Nindjin, C., N'zue, B. Tschannen, A. and Aka D. 2007. "Potentialités de la transformation $\mathrm{du}$ manioc (Manihot esculenta Crantz) en Afrique de l'Ouest". Actes du ler Atelier International, Abidjan, 4-7 juin, 48-79.

Amani, N.G. 2002. Physico-chemical and molecular properties of yam starches (Dioscorea ssp.) Grown in Côte d'Ivoire. Relationship with the stability of gels to technological treatments. State Doctorate Thesis. University of Abobo-Adjamé, 203p.

Anderson, R.A., Conway, H.F., Pfeifer, V.F. and Griffin, E.L. 1969. Roll and extrusion-cooking of grain sorghumgrits. Cer Sci Today, 14: 372380 .

Beuchat, L.R. 1977. Functional and electrophoretic characteristics of succinylated peanut flour protein. J. Agric. Food Chem. 25:258-261.

Bokanga, M. 2001. "CASSAVA: Post-harvest Operations, éd. International Institute of Tropical Agriculture (IITA)", Ibadan, Nigeria, $220 \mathrm{p}$.

Coffman, C.W.L. and Garcia, V.C.1977. Functional properties and amino acid of a protein isolate from mungbean flour. $\mathbf{J}$ Food Technol. 12: 473-484.
Diallo, K.S., Koné, K.Y., Soro, D., Assidjo, N.E., Yao, K.B. and Gnakri, D. 2015. Caractérisation biochimique et fonctionnelles des graines de sept cultivars de voandzou [Vigna subterranea (L.) verdc. fabaceae] cultivés en côte d'ivoire: European scientific journal. 11(27) : 1857-7881.

Djilemo, L. 2007. Cassava flour (Manihot esculenta Crantz) unfermented: The future of cassava cultivation in Africa. In: Cassava International Workshop, Abidjan, Ivory Coast.

Djoulde, D.R. 2005.Mise au point d'un ferment mixte destiné à la bioconversion des tubercules de manioc cyanogène. Thèse de Doctorat Unique, Université de N'Gaoundéré. République du Cameroun, $220 \mathrm{p}$.

Dumont, R. 1995. Utilisation des ignames (Dioscorea sp.) pour la production de cossettes ou de farine destinée au commerce. Situation actuelle et perspectives. Rapport, CIRAD/IITA, Cotonou, République du Bénin. 7p.

Duncan D. B. (1955). Multiple range and Multiple F-tests, Biometrics. 11, 1-42

Eke-Ejiofor, J., Barber, L.I. and Kiin-Kabari, DB. 2011. Effet de précuisson sur le produit chimique, fonctionnel et Propriétés du riz. Collage Journal de l'Agriculture et Science Biology.2 :214219.

Ekwu, F.C., Ozo, N.O. and Ikegwu, OJ. 2005. Qualité de la farine de fufu à partir de variétés d'ignames blanches (Dioscorea spp). Nigerian Food Journal. 23: 107113

Ezeocha, V.C., Omodamiro, R.M., Oti, E. and Chukwu, G.O. 2011. Développement de l'igname trifoliée: farine composite de cocoyam pour la production de fufu.Journal of Stored Products and Postharvest Research. 2: 184-188.

Ezeocha, V.C., Omodamiro, R.M., Oti, E. and Chukwu, GO. 2011. Développement de 
l'igname trifoliée: farine composite de cocoyam pour la production de fufu.Journal of Stored Products and Postharvest Research. 2: 184-188.

Falade, K.O. and Akingbala, JO. 2010. Utilization of cassava for food. Food Rev. Int. 27(1), 51-83.

FAOSTAT. 2011. Food and Agriculture Organization of the United Nations statistics database retrieved 2 February, 2011. www.faostat.fao.org

FAOSTAT. 2014. United Nations Food and Agriculture Organization. Cassava production. http://faostat.fao.org. Accessed October 23.

Fennama, R.O. 1996.Food Chemistry, 3th ed. Marcel Dekker Inc. New York, Basel, Hong Kong. 36-39.

Hillocks, R.J., Thresh, J.M. and Bellotti, A.C. 2002a. Cassava: Biology, Production and Utilization. The origins and taxonomy of cassava (Chapter 1, pp. 111). CABI Publishing. New York, USA.

Himeda, M. 2012. Physicochemical and rheological properties of flour and taro starch (Colocosia esculenta L. Schott) sosso varieties of chad depending on maturity and method of drying.124-152.

Jitngarmkusol, S., Hongsuwankul, J. and Tananuwong, K. 2008. Chemical composition, functional properties and microstructure of defattedm academice flours. Food Chem. 110:23-30

Kakou AC. 2000. Optimisation des conditions d'application d'une méthode conservation longue durée de la pâte de manioc (Manihot esculenta, Crantz) en vue d'améliorer la qualité alimentaire de l'attiéké et du placali. Thèse de $3 \mathrm{e}$ cycle de Biochimie-Microbiologie, Université de Cocody-Abidjan, Côte d'Ivoire, 168p.

Kaur, M., Kaushal, P. and Sandhu, K.S. 2013. Physicochemical Studies and Bonding Properties of Taro Flour (Colocasia esculenta L.) Compared to a Cereal,
Tuber and Legume Flour, J de Food Sci and Tech. 50: 94-100.

Kaushal, P., Kumar, V. and Sharma, HK. 2012. Comparative study of physicochemical, functional, antinutritional and pasting properties of taro (Colocasia esculenta), rice (Oryzasativa), pegionpea (Cajanuscajan) flour and their blends. LWT-Food Sci Technol, 48:59-68.

Kinsella, J.E. 1976. Functional properties of proteins in foods. Critical Reviews in Food Science and Nutrition.1(3): 219280.

Kulkarni, K.D., Kulkarn, I.D.N. and Ingle, UM. 1991. Sorghum malt based weaning food formulations, preparations, functional properties and nutritive values. Food and Nutrition Bulletin. 13:322-329

Maziya-Dixon, B., Dixon, A.G.O. and Adebowale, AA. 2007. International Journal of Food Science and Technology. 42 (8): 969-976.

Mbome, L.I. 1991. Use of the yam Dioscorea dumetorum as a base for weaning porridges. Paper presented at the workshop on weaning porridges in Central Africa, held from 21 to 24 May 1991 in Brazzaville, Congo.

Moorthy, S.N. 2004. Tropical sources of starch, in Starch in food (Ed. A. C. Eliasson). CRC Press, BocaRatón, Fl, 321-359.

Mora-Escobedo, R., Lopez, O.P and Lopez, G.F.G 1991. Effect of germination on the rheological and functional properties of amaranth seeds. LWT Food SciTechnol. 24:241-244.

Mora-Escobedo, R., Robles-Ramirez, M.C, Ramon-Gallegos, E. and Reza-Aleman, R. 2009. Effect of Protein Hydrolysates from Germinated Soybeanon Cancerous Cells of the Human Cervix: An In Vitro Study. Plant Foods for Human Nutrition. 64: 271-278. 
N'Zué, B. Zohouri, G.P. and Kouadio, K. 2001. Introduction de nouvelles variétés de manioc en milieu paysan. In Variétés améliorées de manioc en milieu paysan en Afrique de l'ouest. Actes d'un atelier régional sur le manioc. IITA, Cacavali, Togo, 42-51.

Narayana, K. and Narasinga, R.N.M.S. 1982. Functional properties of raw and heat processed winged bean flour Journal of food Science. 47:1534-1538

Niba, L.L., Bokonga, M.M., Jackson, E.L, Schlimme, D.S and Li, B.W. 2001. Physicochemical Properties and Granular Characteristics of Flour Starch Various Genotypes of Manihot esculenta (Cassava), Journal of Food Science. 67(5). 1701-1705.

Njintang, Y.N. and Mbofung, C.M.F. 2003. Kinetics of gelatinisation and mass transfer during cooking of taro (Colocasia esculenta L. Schott) slices. Starch/Stärke. 55, 170-176.

Njintang, Y.N., Mbofung, C.M.F. and Waldron, K.W. 2001. In vitro protein digestibility and physico-chemical properties of dry red bean (Phaseolus vulgaris) flour: effect of processing and incorporation of soybean and cowpea flour. Journal ofAgriculture and Food Chemistry. 49, 2465-2471.

Nweke, F.I., Spencer, D. S.C. and John, K.L. 2002. The cassava transformation; Africa's best kept secret. Michigan State University Press, East Lansing, MI.

Onuegbu, T.U., Ekpunobi, U.E., Ogbu, I.M., Ekeoma, M.O. and Obumselu, F.O. 2012. Comparative studies of ignition time and water boiling test of coal and biomass briquettes blend, International Journal of Research \& Reviews in Applied Sciences. 7 :153-159.

Onwuka, G. 2005. Food Analysis and Instrumentation: Theory and Practice, 1th ed, Naphtali Prints, Lagos, Nigeria, $129 \mathrm{p}$.

Perez, E., Schultzb, F.S. and Pacheco de Delahaye, E. 2005. Caractérisation de certaines propriétés des amidons isolés de Xanthosoma Saggitifolium (tannia) et Colocasia esculenta (taro) Carbohydr Polym. 60:139-145.

Phillips, R.D, Chinnan, M.S, Branch, A.L., Miller, J. and Mcwatters, K.H. 1988. Effects of pretreatment on functional and nutritional properties of cowpeameal. J Food Sci. 53: 805-809.

Sahay, K.M, Singh, K.K. $1996 . \quad$ Unit operations of Agricultural Processing. Vikas Publishing House Pvt. Ltd. New Delhi. P. 237p.

Sara, Y.H., Nafisa, M.H., Amro, B.H., Mohamed, M.E. and Elfadil, E.B. 2008. Nutritional Evaluation and Physiochemical Properties of Processed Pumpkin (Telfairia occidentalis Hook) Seed Flour. Pakistan Journal of Nutrition. 7 (2): 330-334

Schuck, P. 2011. Changes in Functional Properties of Dairy Protein Powders: Impact of Concentration and Drying, Agronomic Innovations. 13: 71-99.

Singh, A., Hung, Y., Corredig, M., Phillips, R.D., Chinnan, M.S. and McWatters, K.H. 2005. "Effect of milling method on selected physical and functional properties of cowpea (Vigna unguiculata) paste", International Journal of Food Science and Technology. 40: 525-536.

Sodjinou, R.S. 2006. Evaluation of food composition tables commonly used in Benin: Limitations and suggestions for improvement. J. Food Comp. Anal. 19: 518-523.

Sosulski, F.W. 1962. The centrifuge method for determining flour absorption in hard red spring wheats. Cereal Chem. 39:344-350. 
Ubbor, S.C., Akobundu, E.N.T. and Onwuka, GI. 2006. Functional properties and cyanide content of starch and selected cassava flour (Manihot esculenta Crantz) varieties resistant to mosaic (CMD). Journal of Raw Materials Res. 3 (2): 4 - 15.

Udensi, E.A. and Okaka, JC. 2000. Predict the effect of bleaching, drying temperature and particle size profile on the dispersibility of cowpea flour. Nigerian Food Journal. 18: 25-31.

Westby, A. 2002. Cassava Utilization, Storage and Small-scale Processing. In: Cassava: Biology, Production and Utilization. Editions Belloti A.C., Thresh J.M. and Hillocks R.C. CAB
International, Wallingford, Oxon, UK, 281-300.

Zoumenou, V. 1994. Etude physico-chimique et nutritionnelle de quelques préparations alimentaires à base de manioc (Manihot esculenta Crantz) : thèse de doctorat 3ème cycle, FAST, Université nationale, Côte d'Ivoire, $101 p$.

Zuluaga, M.F., Baena, Y., Mora, C.E. and D'Leon, LF.P. 2007.Caractérisation physico-chimique et application de l'igname (Dioscorea cayenensisrotundata) Amidon comme excipient pharmaceutique.Starch / Stärke. 59: 307-317

\section{How to cite this article:}

Marise Amaco Kacou, Gbocho Serge Elvis Ekissi, Bomo Catherine Ebbah-Djedji, Boni N'zué and Patrice Lucien Kouamé. 2018. Assessment of Functional Properties Flours from Seven Local Varieties of Cassava (Manihot esculenta Crantz) Consumed in Côte d'Ivoire. Int.J.Curr.Microbiol.App.Sci. 7(10): 815-826. doi: https://doi.org/10.20546/ijcmas.2018.710.090 